\title{
Analisis Rantai Pasok (Supply Chain) Garam Rakyat di Kabupaten Pidie, Aceh
}

\author{
Teuku Athaillah1)* \\ Yoga Nugroho') \\ 1)2)Program Studi Agribisnis Fakultas Pertanian Universitas Teuku Umar \\ *email : athaillah.teuku@gmail.com \\ Diterima: April 2019; Disetujui: September 2019; Dipublish: Oktober 2019
}

\begin{abstract}
Abstrak
Adapun tujuan dari penelitian ini adalah untuk menganalisis aliran produk, aliran keuangan dan aliran informasi pada rantai pasok garam rakyat di Kabupaten Pidie, Aceh. Teknik pengambilan sampel yang digunakan adalah non probability sampling yaitu teknik snowball sampling. Aliran produk, aliran keuangan, dan aliran informasi adalah tiga aspek yang diteliti. Analisis akan mengikuti metode SCOR (Supply Chain Operation Reference) untuk melihat performance rantai pasok dengan melihat proses Plan, Source, Make, dan Deliver. Hasil penelitian menunjukkan dua tipe rantai pasok, tergantung apakah petani memiliki kesepakatan dengan pedagang pengumpul atau tidak. Bagi petani yang memiliki kesepakatan dengan pedagang pengumpul, garam hasil produksi dijual kepada pedagang pengumpul yang selanjutnya dijual kepada agen penjual. Agen penjual meneruskannya ke penjual grosir yang kemudian di distribusikan kepada pedagang eceran dan konsumen. Aliran keuangan berjalan dari arah sebaliknya, kecuali pada saat pembelian bahan baku kayu bakar, agen pengumpul yang membayarkannya untuk petani. Sedangkan bagi petani yang tidak memiliki kerjasama dengan agen pengumpul, garam langsung dijual kepada pedagang eceran atau konsumen. Aliran keuangan berjalan dari arah sebaliknya untuk kedua jenis rantai pasok dan aliran informasi berjalan dua arah. Kendala utama pada rantai pasok garam adalah tidak sampainya informasi tentang harapan dari perusahaan besar terhadap garam yang dihasilkan petani. Selain itu, perusahan besar merasa bahwa kualitas produk yang dihasilkan petani tidak konsisten.
\end{abstract}

Kata Kunci : Supply chain; Garam rakyat; SCOR.

\begin{abstract}
The purpose of this research is to analyze the product, financial, and information flow in the local salt supply chain in Pidie Regency, Aceh. The sampling technique used is non-probability sampling, precisely the snowball sampling technique. Product flow, financial flow, and information flow were three elements that investigated. The analysis based on the SCOR (Supply Chain Operation Reference) method to see supply chain performance by studying at the Plan, Source, Make, and Deliver process. The results showed two types of supply chains, depends on whether farmers have an agreement with the collecting agent or not. For farmers who had a deal with the collecting agent, The salts are sold to the collecting agent and then forwarded to the selling agent. The selling agent passes it on to the wholesale seller, who then distributed to retailers and consumers. The flow of finance goes from the opposite direction, except when purchasing raw materials for firewood, the collecting agent pays it first to the farmers. To farmers who did not have agreements with collecting agents, the salt directly sold to retail stores or consumers. Financial flows run in the opposite direction for both types of supply chains, and information flow goes both ways. The main obstacle in the salt supply chain is the lack of information between salt producer and consumers expectations.
\end{abstract}


Moreover, it is often difficult for large customers to believe that the quality of farmers' salt will be consistent.

Keyword : supply chain; local salt; SCOR.

\section{PENDAHULUAN}

Garam sudah menjadi kebutuhan sekunder masyarakat Aceh. Hampir setiap masakan di Aceh menggunakan garam sebagai penguat rasa. Bukan hanya untuk makanan, garam juga dibutuhkan untuk berbagai industri seperti industri kosmetik dan bahan obat-obatan. Oleh sebab itu ketersediaan garam untuk bahan makanan dan bahan baku industri harus selalu ada untuk memenuhi kebutuhan masyarakat dan kebutuhan industri.

Bahan baku utama untuk pembuatan garam adalah air laut. Indonesia memiliki laut yang sangat luas bila dibandingkan dengan negaranegara lain seperti Vietnam dan Thailand. Kekurangan stok garam yang menyebabkan Indonesia mengimpor garam pada tahun 2018 menjadi tanda tanya besar. Salah satu penyebabnya adalah terdapat berbagai masalah pada rantai pasok (supply chain) garam yang menyebabkan terhambatnya aliran rantai pasok garam.

Wuwung (2013) mengatakan Rantai pasok menggambarkan seluruh proses dan kegiatan yang bertujuan menyampaikan produk kepada konsumen. Assauri (2011) menyatakan Supply chain menyangkut hubungan yang terus-menerus mengenai barang, uang dan informasi. Barang umumnya mengalir hulu ke hilir,uang mengalir dari hilir ke hulu, sedangkan informasi mengalir dua arah dari hulu ke hilir maupun hilir ke hulu.

Kinerja rantai pasok merupakan hasil dari berbagai upaya yang dilakukan setiap anggota rantai pasok untuk memenuhi tujuan akhir rantai pasok, yaitu kepuasan konsumen (Sari et al. 2014). Saling ketergantungan dalam rantai pasok akan menciptakan hubungan jangka panjang yang saling membutuhkan. Sehingga ketersediaan produk dan ketepatan waktu pengiriman akan tercapai (Rahmasari, 2011). Sebuah produk akan sampai ke tangan konsumen akhir setelah setidaknya melalui beberapa proses dari pencarian bahan baku, proses produksi dan proses distribusi atau tansportasi (Prasetya, 2009).

Terhambatnya proses produksi garam menjadi salah satu penyebab kekurangan stok garam di Indonesia. Kebutuhan industri akan garam yang cukup banyak serta kurangnya stok garam menyebabkan Pemerintah Indonesia mengizinkan impor garam. Adapun quota impor garam Indonesia pada tahun 2013 adalah 1,9 juta ton, pada tahun 2014 impor garam sebanyak 2,2 juta ton, tahun 2015 sebanyak 1,8 
juta ton, pada tahun 2016 sebanyak 2,1 juta ton, dan pada tahun 2017 naik menjadi 2,5 juta ton (BPS, 2018). Pemerintah Indonesia sepakat untuk mengeluarkan izin impor garam sebanyak 3,7 juta ton pada tahun 2018 (Kemenperin, 2018).

Ada berbagai jenis informasi yang bisa dibagi dalam rantai pasokan, termasuk logistik, bisnis, strategis, taktis dan sebagainya. Beberapa jenis Informasi yang sering dibagikan dalam rantai pasok dapat dikategorikan sebagai: 1) Informasi Inventory; 2) Data penjualan; 3) Ramalan penjualan; 4) Informasi Pemesanan; 5) Informasi kemampuan produk di pasar ; 6)Informasi eksploitasi produk Baru; dan 7) Informasi Lainnya (Lotfi, 2013).

Terdapat dua desa penghasil garam rakyat di Kabupaten Pidie yaitu Desa Cebrek dan Desa Ie Lebeu. Untuk melihat bagaimana supply garam di Kabupaten Pidie, peneliti berkeinginan untuk meneliti tentang rantai pasok garam dengan judul penelitian. Adapun tujuan dari penelitian ini adalah untuk menganalisis aliran produk, aliran keuangan dan aliran informasi pada rantai pasok garam di Kabupaten Pidie serta menganalisis performance rantai pasok dengan mengikuti metode SCOR (Supply Chain Operation Reference).

\section{METODE PENELITIAN}

Penelitian ini akan dikhususkan pada rantai pasok garam yang berasal dari Desa penghasil garam di Kabupaten
Pidie, yaitu Desa Cebrek dan Desa Ie Leubeu. Objek dalam penelitian ini adalah pihak-pihak yang terlibat dalam rantai pasok garam. Ruang lingkup penelitian ini dibatasi pada masalah aliran supply chain garam di Kabupaten Pidie, Aceh.

Teknik pengambilan sampel yang akan digunakan dalam penelitian ini menggunakan non probability sampling yaitu teknik snowball sampling. Snowball sampling digunakan untuk mengalisis aliran produk, keuangan, dan informasi dalam rantai pasok (Athaillah, 2018). Snowball (bola salju) mengambil sejumlah kasus melalui hubungan keterkaitan dari satu orang dengan orang yang lain atau satu kasus dengan kasus lain, kemudian mencari hubungan selanjutnya melalui proses yang sama, demikian seterusnya (Nurdiani, 2014). Snowball sampling adalah suatu pendekatan untuk menemukan informan-informan kunci yang memiliki banyak informasi.

Data dianalisis secara deskriptif kualitatif, yaitu analisis gambaran secara lengkap tentang rantai pasok garam di Pidie. Ada 3 komponen yang akan diteliti yaitu aliran produk, aliran keuangan, dan aliran informasi pada rantai pasok garam di Pidie. Analisis akan mengikuti metode SCOR (Supply Chain Operation Reference) untuk melihat performance rantai pasok. Menurut Pujawan (2010), SCOR membagi proses-proses rantai pasokan menjadi Plan (proses perencanaan), Source (proses 
pengadaan), Make (proses produksi), dan Deliver (proses pengiriman).

\section{HASIL DAN PEMBAHASAN}

Lebih dari 95\% garam yang dihasilkan oleh petani garam di wilayah pidie adalah garam yang direbus secara tradisional. Garam rebus adalah garam yang dihasilkan melalui proses perebusan air asin dengan menggunakan kayu bakar. Adapun proses untuk membuat garam rebus adalah sebagai berikut :

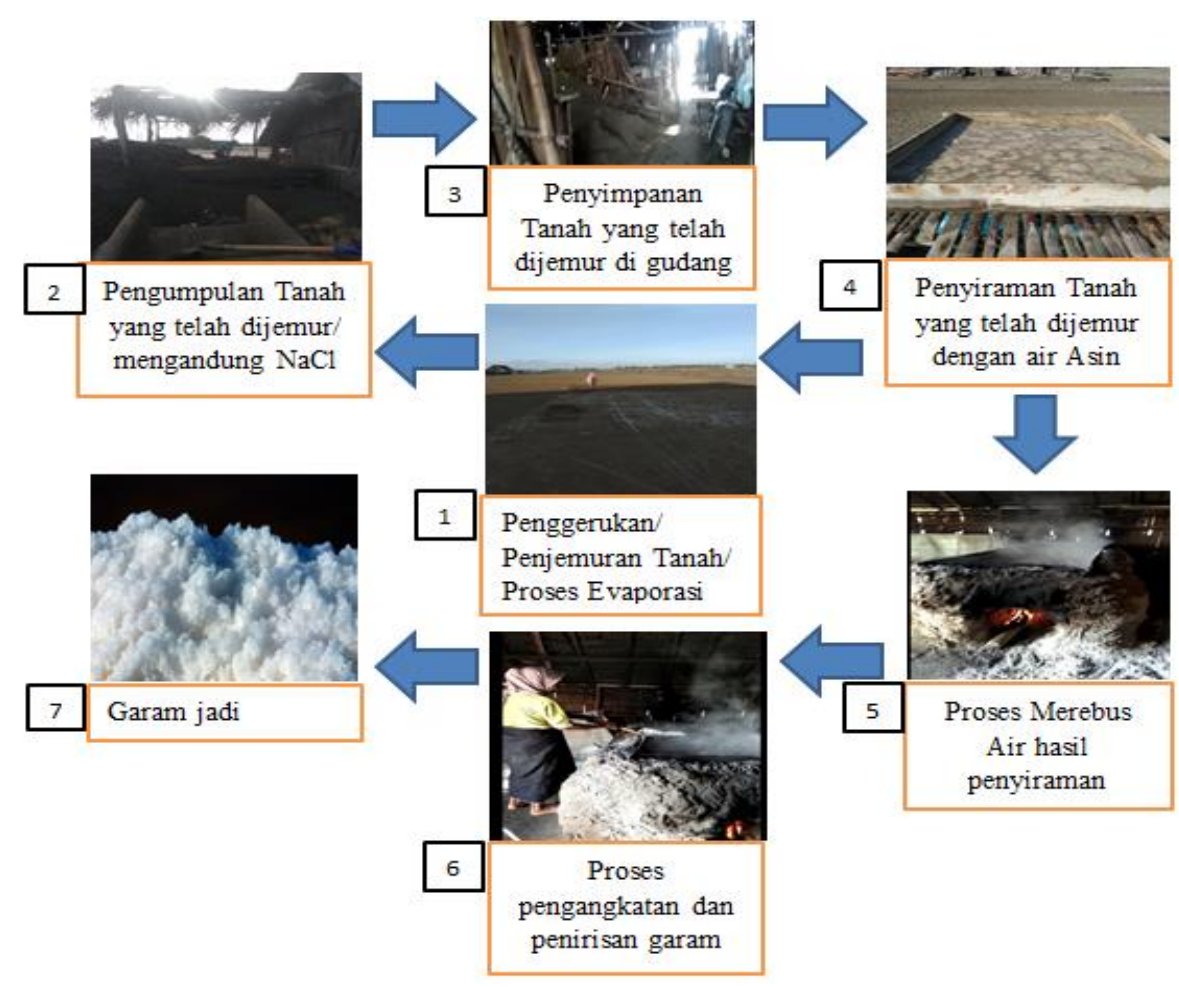

Gambar 1. Proses Pembuatan Garam dengan cara merebus di Pidie

Pada Gambar 1 dapat dilihat proses pembuatan garam yang dilakukan oleh petani garam di Pidie. Pembuatan garam dimulai dengan penggerukan tanah yang telah mengandung $\mathrm{NaCl}$ atau setelah melalui proses evaporasi. Proses evaporasi menarik air dari dalam tanah beserta dengan $\mathrm{NaCl}$ ke permukaan, air kemudian menguap dan meninggalkan garam di permukaan tanah. Permukaan tanah tersebut kemudian digaruk oleh petani garam dan tanah tersebut kemudian dikumpulkan dan disimpan di gubuk/gudang.

Tanah yang yang dikumpulkan tersebut bisa disimpan berhari-hari sebelum digunakan. Penyimpanan ini juga berfungsi agar tersedianya stok 
untuk membuat garam jika hujan turun. Pada saat musim hujan, permukaan tanah dibasahi oleh air hujan dan tidak dapat diambil oleh petani. Petani bisa menyimpan stok tanah dalam gubuk hingga seminggu penggunaan.

Petani garam membuat semacam saringan dan meletakkan tanah diatas saringan tersebut. Tanah yang telah mengandung $\mathrm{NaCl}$ tersebut kemudian disiram dengan air yang juga mengandung $\mathrm{NaCl}$ dari sumur yang digali oleh petani disekitaran lahan garam. Air saringan tersebut kemudian ditampung oleh petani dan kemudian direbus. Tanah yang telah disiram dan telah diambil airnya kemudian di jemur ulang selama 2 hari dan kembali seperti proses awal.

Air saringan direbus selama 4 sampai 5 jam hingga menjadi garam. Garam tersebut kemudian diangkat dan ditiriskan selama \pm 2 jam hingga kering. Petani menghasilkan 80-100 kg garam untuk sekali rebus tergantung dari ukuran dapur yang digunakan dan kadar garam yang ada dalam air tersebut. Dalam sehari petani bisa menghasilkan maksimal $200 \mathrm{~kg}$ garam perdapur rebus. Adapun aliran rantai pasok garam di Kabupaten Pidie adalah sebagai berikut:

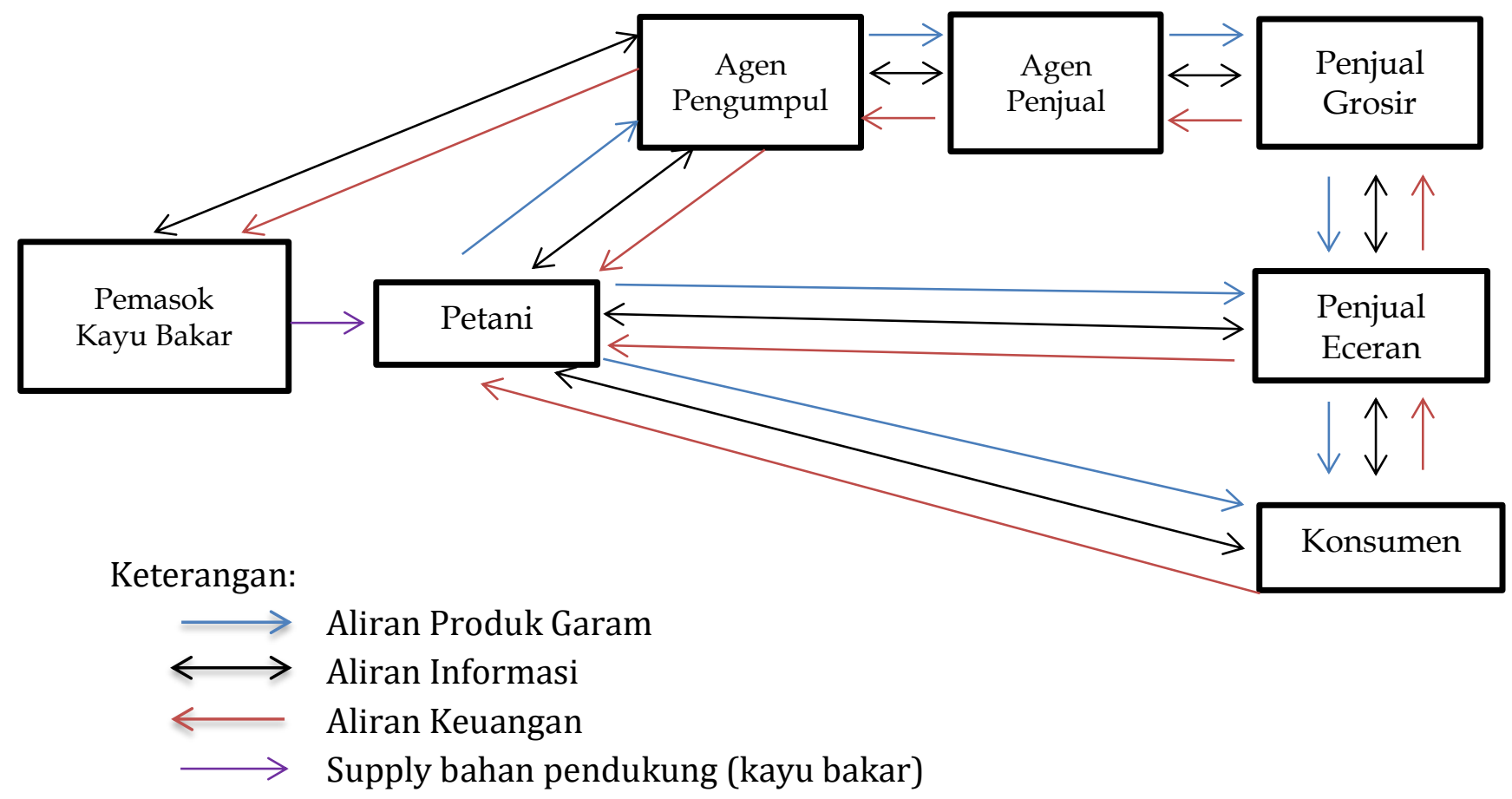

Gambar 2. Aliran Produk, Aliran Keuangan, dan Aliran Informasi Rantai Pasok Garam di Pidie

Pada Gambar 2 dapat dilihat aliran produk garam yang dihasilkan oleh

petani garam diwillayah Pidie. Berbeda dengan garam jemur, untuk membuat 
garam rebus petani sangat memerlukan pasokan kayu bakar. Kayu bakar digunakan oleh petani untuk merebus air yang mengandung garam sehingga menjadi garam.

Petani tidak berhubungan langsung dengan pemasok kayu bakar. Pemasok kayu bakar mengantarkan kayu bakar kepada petani garam setelah sepakat mengenai jumlah dan harga dengan agen pengumpul. Agen pengumpul yang membayarkan kayu bakar untuk petani. Petani berhutang harga kayu bakar dengan agen penempung dan harus dibayarkan dengan garam jadi. Fenomena ini yang membuat petani garam tidak bisa menjual garam kepada selain agen pengumpul yang telah membelikan kayu bakar kepada petani.

Lebih dari 90\% petani garam di Desa Cebrek Kabupaten Pidie menggunakan kayu bakar yang di beli oleh agen pengumpul dan membayarnya dengan garam jadi. Hanya sebagian kecil yang menggunakan kayu bakar yang dicari sendiri. Sedangkan di Desa Ie Leubeu Kabupaten Pidie Hampir semua petani garam menggunakan kayu yang dicari atau dibeli sendiri. Harga untuk 1 truk kayu bakar berkisar antara 800 ribu sampai 1 juta rupiah. 1 truk kayu bakar bisa menghasilkan \pm 1 ton garam jadi.

Petani garam yang menggunakan kayu bakar dari agen pengumpul berkewajiban/harus menjual garamnya kepada agen pengumpul. Dapat dilihat pada gambar 2, Aliran garam dari petani kepada agen pengumpul didominasi oleh petani yang menggunakan kayu bakar yang dibeli oleh agen pengumpul. Agen pengumpul membeli garam dari petani dengan kisaran harga $\mathrm{Rp} 2.500$ sampai $\mathrm{Rp} 3.500 / \mathrm{kg}$ tergantung harga beli pasar.

Agen pengumpul memiliki gudang dengan daya tampung 500 ton garam untuk menampung garam yang dibeli pada petani di Desa Cebrek. Garam tersebut kemudian dijual kepada agen penjual dengan kisaran harga Rp 3.700 sampai dengan Rp 5.000/kg tergantung harga pasar. Agen penjual datang ke gudang agen pengumpul untuk membeli garam. Biaya transportasi untuk memindahkan garam dari gudang hingga terjual ke penjual grosir seluruhnya dibebankan kepada agen penjual.

Berbeda dengan Desa Cebrek, di Desa Ie Leubeu tidak ada agen pengumpul garam. Petani garam di Desa Ie Leubeu juga menggunakan kayu bakar yang di cari sendiri atau dibeli sendiri. Petani biasanya langsung menjual garam ke penjual eceran dengan harga $\mathrm{Rp}$

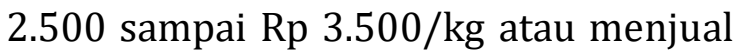
langsung garam kepada konsumen dengan harga Rp 3.500 sampai Rp 5.000 tergantung harga pasar dan banyaknya garam yang dibeli konsumen. Petani garam di Desa Ie Leubeu menunggu penjual eceran atau konsumen datang membeli garam. Petani garam di Desa Ie Leubeu juga bebas menjual garam 
kepada siapapun tidak terikat dengan agen pengumpul.

\section{Plan (Proses perencanaan)}

Keterbatasan gudang penyimpanan membuat petani tidak berproduksi dalam skala besar. Petani di Desa Cebrek berproduksi sesuai arahan agen pengumpul. Petani akan berhenti berproduksi pada saat gudang agen pengumpul penuh. Sementara di Desa Ie Leubeu petani juga tidak bisa berprodukusi dalam skala banyak. Petani menunggu pembeli datang dan baru berproduksi kembali pada pada saat garam habis terjual.

Dalam hal distribusi, sebagian besar petani garam menyerahkan perencanaan distribusi sepenuhnya kepada agen pengumpul. Agen pengumpul yang menentukan seberapa banyak petani harus berproduksi. Keterbatasan jaringan dalam distribusi membuat agen pengumpul kesulitan untuk menjual garam dari petani, Akibatnya petani sering tidak berproduksi.

Seperti yang ditunjukkan pada gambar 2, Agen pengumpul menyalurkan garam yang di beli dari petani kepada agen penjual yang diteruskan ke pedagang pengecer. Tidak adanya pelanggan dari perusahanperusahaan besar membuat agen pengumpul kesulitan memasarkan garam dari petani.

Situasi ini tentu berbanding terbalik dengan fakta dilapangan dimana pemerintah mengimpor ratusan ribu ton garam pada tahun 2019. Sementara kebanyakan petani berhenti produksi sementara waktu (tidak berproduksi secara maksimal) karena garam belum laku terjual. Petani garam mengeluhkan banyaknya impor garam yang masuk pada tahun 2019.

Salah satu aliran informasi yang tidak sampai kepada petani garam adalah informasi kemampuan produk dipasar. Terdapat aliran informasi yang sumbang dan tidak sampai kepada petani, dimana pihak dari Industri memerlukan bahan baku garam dengan kandungan $\mathrm{NaCl}$ 97\%. Sedangakan garam yang diproduksi oleh petani adalah garam dengan kandungan $\mathrm{NaCl}$ berkisar antara 92-94\%. Untuk memasarkan garamnya ke industri petani harus bisa menghasilkan garam dengan kadar kandungan $\mathrm{NaCl}$ 97\%.

Berdasarkan hasil wawancara dengan Kepala Seksi Sarana dan Prasarana Dinas Kelautan dan Perikanan Kabupaten Pidie, banyak perusahaan pengguna bahan baku garam tidak ingin menjalin kerjasama dengan petani garam lokal karena ketidak percayaan perusahaan dengan kualitas garam yang dihasilkan dan konsistensi produksi petani agar bisa memenuhi kebutuhan bahan baku perusahaan sepanjang tahun. Perusahaan melihat dari output garam yang dihasilkan petani setiap tahunnya yang sangat kurang. Padahal petani bisa saja memenuhi kebutuhan perusahaan jika berproduksi secara 
maksimal dan konsisten sepanjang tahun. Informasi kemampuan produksi petani garam seharusnya sampai kepada perusahaan-perusahaan yang menggunakan bahan baku garam.

\section{Source (Pengadaan bahan baku)}

Bahan baku untuk membuat garam rebus seperti air dan tanah sangat mudah didapatkan oleh petani. Petani membuat sumur air asin di sekitar lokasi pembuatan garam. Air sumur tersebut digunakan petani untuk menyiram tanah yang telah melalui proses evaporasi dan kemudian air hasil penyiraman kembali ditampung untuk di rebus menjadi garam.

Petani juga mempunyai lahan untuk proses penjemuran tanah agar berlangsungnya proses evaporasi. Setelah berlangsungnya proses evaporasi, tanah yang dijemur tersebut kemudian di geruk. Tanah tersebut disimpan didalam gubuk. Untuk satu kali proses penjemuran, tanah yang yang digeruk tersebut bisa menghasilkan 10 14 dapur air garam, atau bisa digunakan untuk 5-7 hari.

Untuk stok bahan baku kayu bakar, sebagian besar petani bekerja sama dengan agen pengumpul. Pada saat kayu habis, petani langsung meminta kepada agen pengumpul untuk dibelikan kayu bakar. Aliran informasi dan keuangan lancar dan tidak ada kendala berarti. Petani yang tidak menggunakan kayu bakar dari agen pengumpul biasanya membeli atau mencari kayu bakar sendiri. Tidak ada kendala berarti pada proses pengadaan baku (source).

\section{Make (proses produksi)}

Jumlah dapur produksi garam di Desa Cebrek Kabupaten Pidie adalah 200 dapur produksi. Jika semua dapur beroperasi jumlah garam yang bisa dihasilkan maksimal 40 ton/hari. Bila dikalkulasikan pertahun, Desa Cebrek bisa menghasilkan 14.600 ton garam/tahun. Sementara di Desa Ie leubeu Kabupaten Pidie terdapat 80 dapur garam. Jika semua dapur beroperasi Desa Ie Leubeu bisa menghasilkan maksimal 16 ton garam perhari, dan menghasilkan 5.840 ton garam/tahun. Jika ditotalkan, petani garam di Kabupaten Pidie bisa menghasilkan lebih dari 20.000 ton garam pertahun.

Akan tetapi kenyataan dilapangan, petani tidak pernah menghasilkan lebih dari 6.000 ton garam pertahun di Pidie. Kendala sebenarnya bagi petani adalah tidak adanya pasar yang menampung garam yang dihasilkan petani. Petani sering menunda berproduksi karena garam yang telah diproduksi belum habis terjual.

Petani di Desa Cebrek tidak berproduksi setiap hari. Petani menunggu arahan/perintah dari agen pengumpul untuk memproduksi garam. Pada saat stok melimpah dan gudang agen pengumpul penuh, agen pengumpul akan memberitahukan kepada petani untuk berhenti 
berproduksi sementara waktu. Petani menunggu garam yang ada di agen pengumpul habis terjual kemudian baru mendapatkan arahan untuk berproduksi kembali.

Petani di Desa Ie Leubeu juga tidak berproduksi maksimal. Petani menunggu pembeli (pedagang eceran atau konsumen) datang untuk membeli garam. Petani menunggu sampai garam habis terjual kemudian baru berproduksi kembali. Biasanya petani hanya berproduksi 3 hari dalam seminggu pada hari-hari biasa. Petani hanya berproduksi maksimal pada saat permintaan garam tinggi pada hari besar seperti hari meugang dan lebaran haji.

\section{Deliver (proses pengiriman)}

Aliran produk garam dapat dilihat pada gambar 2, sebagian besar garam dijual petani kepada agen pengumpul. Agen pengumpul akan mendatangi petani untuk mengumpulkan garam. Garam tersebut kemudian disimpan digudang milik agen pengumpul. Agen pengumpul kemudian menunggu agen penjual untuk mengambil garam di gudang. Selain membeli garam dari agen pengumpul, agen penjual juga bertugas mencari pelanggan dan mendistribusikan garam kepada penjual grosir. Penjual grosir membeli garam dari agen penjual dengan pembayaran langsung atau menunda pembayaran sampai garam habis terjual, tergantung dari kesepakatan. Pada saat garam habis terjual, penjual grosir akan menghubungi agen penjual untuk memasok garam kembali.

Kendala utama pada aliran informasi adalah tidak sampainya informasi tentang harapan dari perusahaan-perusahaan besar pengguna bahan baku garam terhadap produk garam yang dihasilkan petani. Informasi konsistensi produksi petani juga diragukan perusahaan besar sehingga perusahaan tidak bekerjasama dengan petani garam.

\section{SIMPULAN}

Aliran produk garam bagi petani yang menggunakan kayu bakar dari agen pengumpul, garam dijual kepada agen pengumpul. Agen pengumpul kemudian menunggu agen penjual untuk mengambil garam di gudang. Penjual grosir membeli garam dari agen penjual dan kemudian di distribusikan kepada pedagang eceran dan konsumen. Aliran keuangan berjalan dari arah sebaliknya, kecuali pada saat pembelian bahan baku kayu bakar. Agen pengumpul yang membayarkannya untuk petani. Sedangkan aliran informasi berjalan dua arah. Aliran produk garam bagi petani yang tidak menggunakan kayu bakar dari agen pengumpul, garam langsung dijual petani kepada pedagang eceran ataupun konsumen. Aliran keuangan berjalan dari arah sebaliknya dan aliran informasi berjalan dua arah. Kendala utama pada rantai pasok garam terdapat pada aliran informasi dimana tidak sampainya informasi tentang harapan 
dari perusahaan terhadap produk garam yang dihasilkan petani. Selain itu, perusahan besar merasa bahwa kualitas produk yang dihasilkan petani tidak konsisten. Diharapkan kepada Pemerintah Kabupaten Pidie untuk membantu mencarikan solusi agar garam hasil produksi petani mencapai kadar kandungan $\mathrm{NaCl}$ 97\% seperti yang dibutuhkan perusahaan. Diharapkan dibuatkan gudang penyimpanan khusus untuk petani garam agar petani bisa berproduksi setiap hari tanpa risau tidak ada gudang penyimpanan.

\section{DAFTAR PUSTAKA}

Assauri, S. 2011. Manajemen Produksi dan Operasi. Lembaga Penerbit FEUI. Jakarta.

Athaillah T, Hamid AH, Indra. 2018. Analisis Efisiensi Kinerja Rantai Pasok Ikan Tuna Pada CV. Tuah Bahari dan PT. Nagata Prima Tuna di Banda Aceh. Marine Fisheries. 9 (2)

BPS. 2018. Statistik Indonesia 2018. Badan Pusat Statistik.

https://kemenperin.go.id/artikel/18952/R ekomendasi-Impor-GaramDikeluarkan-Kemenperin. Diakses 07 juli 2019.
Lotfi, Z. 2013. Information Sharing in Supply Chain Management. Elsevier Procedia Technology 11: 298 304.

Nurdiani, N. (2014). Teknik Sampling Snowball dalam Penelitian Lapangan. Architecture Department, Faculty of Engineering. Jurnal ComTech Vol. 5 (2).1110-1118.

Prasetya H. 2009. Mengelola Rantai Pasokan dan Informasi dalam Memenangkan Persaingan. Prestasi. 5 (2): 44-56.

Pujawan, I Nyoman dan ER, Mahendrawati. 2010. Supply Chain Management. Penerbit Gunawidya. Surabaya

Rahmasari, L. 2011. Pengaruh Supply Chain Management Terhadap Kinerja perusahaan dan Keunggulan Bersaing : Studi Kasus pada Industri Kreatif di Provinsi Jawa Tengah. Majalah Ilmiah Informatika 2 (3).

Sari SW, Nurmalina R, Setiawan B. 2014. Efesiensi kinerja rantai pasok ikan lele di Indramayu Jawa barat Jurnal Manajemen \& Agribisnis. 11 (1): 12-23.

Wuwung SC. 2013. Manajemen Rantai Pasokan Produk Cengkeh Pada Desa Wawona Minahasa Selatan. Jurnal EMBA. 1 (3): 230-238. 